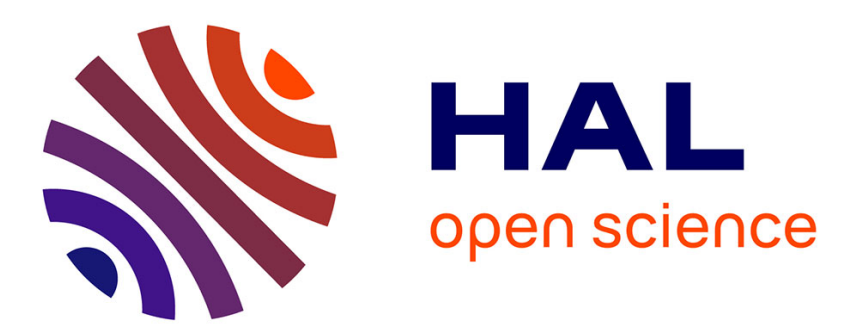

\title{
Protein and peptide research applied to Covid-19 and SARS-Cov-2
}

\author{
Hélène Gagnière, Patrick Di Martino
}

\section{To cite this version:}

Hélène Gagnière, Patrick Di Martino. Protein and peptide research applied to Covid-19 and SARS-Cov-2. Open Access Research Journal of Biology and Pharmacy, 2021, 2 (1), pp.027-028. 10.53022/oarjbp.2021.2.1.0037 . hal-03326184

\section{HAL Id: hal-03326184 \\ https://hal.science/hal-03326184}

Submitted on 25 Aug 2021

HAL is a multi-disciplinary open access archive for the deposit and dissemination of scientific research documents, whether they are published or not. The documents may come from teaching and research institutions in France or abroad, or from public or private research centers.
L'archive ouverte pluridisciplinaire HAL, est destinée au dépôt et à la diffusion de documents scientifiques de niveau recherche, publiés ou non, émanant des établissements d'enseignement et de recherche français ou étrangers, des laboratoires publics ou privés. 


\title{
Open Access Research Journal of Biology and Pharmacy
}

Journals home page: https://oarjbp.com/

ISSN: 2782-9979 (Online)

(LETTERTO EDITOR)

\section{Protein and peptide research applied to Covid-19 and SARS-Cov-2}

\author{
Hélène Gagnière ${ }^{1}$ and Patrick Di Martino 2,* \\ ${ }^{1}$ Ecole de Biologie Industrielle, 49 Avenue des Genottes, 95800 Cergy, France. \\ ${ }^{2}$ Laboratoire ERRMECe, CY Cergy-Paris Université, 1 rue Descartes, 95000 Neuville-sur-Oise, France.
}

Open Access Research Journal of Biology and Pharmacy, 2021, 02(01), 027-028

Publication history: Received on 24 July 2021; revised on 07 August 2021; accepted on 09 August 2021

Article DOI: https://doi.org/10.53022/oarjbp.2021.2.1.0037

\begin{abstract}
The emergence of SARS-Cov-2 remains a challenge for the global scientific community. Many efforts have been made to rapidly develop vaccines against SARS-Cov-2. Currently available vaccines, based on the spike glycoprotein (S), are effective in generating neutralising antibodies to prevent severe acute forms of Covid-19. However, the emergence and spread of SARS-Cov-2 variants with mutations in the S protein raises questions about the need to adapt the vaccine strategy to the evolution of the virus. Proteome analysis of many SARS-Cov-2 clinical isolates suggests the development of vaccines based on peptides corresponding to epitopes located in the constant regions of viral proteins that could be effective despite the appearance of variants or the emergence of new strains of beta coronavirus. Other therapeutic innovations against Covid-19 could come from the development of peptides that inhibit structural and non-structural viral proteins. Beyond the therapeutic aspects, research on Covid-19-related proteins and peptides is also directed towards the development of diagnostic tools. The study of the glycosylation of viral proteins and the ACE-2 receptor is important for the development of therapies and diagnostics.
\end{abstract}

Keywords: Covid-19; SARS-Cov-2; Vaccine; Peptide; Glycosylation

\section{Introduction}

The emergence of SARS-Cov-2 has been a challenge for the global scientific community for almost two years [1]. A major avenue of research to combat Covid-19 is the development of vaccines against SARS-Cov-2 [2]. SARS-Cov-2 is a betacoronavirus of the Coronaviridae family [3]. This virus has a $30 \mathrm{~kb}$ RNA genome with fourteen ORFs that allow the expression of four major structural proteins called E (envelope), M (membrane), N (nucleocapsid), and S (spike) proteins. The S protein is a homotrimer composed of two functional subunits, S1 and S2, involved in cell receptor binding and membrane fusion, respectively. Entry of SARS-Cov-2 into human cells requires high-affinity interaction with the angiotensin converting enzyme 2 (ACE2) receptor. Vaccine development against SARS-Cov-2 has been largely focused on the $\mathrm{S}$ glycoprotein, which is the dominant surface antigen of the virus particle. Currently available vaccines are effective in generating neutralising antibodies to prevent severe acute forms of Covid-19. However, the emergence and spread of SARS-Cov-2 variants with mutations in the S protein raises questions about the need to adapt the vaccine strategy to the evolution of the virus [4]. In addition to the S protein, epitopes that can stimulate B and T cells have been identified in the $\mathrm{M}$ and $\mathrm{N}$ proteins [5]. Proteome analysis of numerous SARS-Cov-2 clinical isolates has identified the most frequent mutations and shown that some non-structural viral proteins are highly resistant to mutation [6]. This may allow the development of vaccines based on peptides corresponding to epitopes located in constant regions of viral proteins that could be effective despite the appearance of variants or the emergence of new strains of Beta coronavirus. Further therapeutic innovations against Covid-19 could come from the development of peptides that inhibit viral proteins [7-9]. These peptides target structural proteins of the virus such as the receptor binding domain of the spike protein, or the activity of non-structural proteins such as main protease (Mpro) involved in the cleavage of viral polyproteins, or 2'-O-methyltransferase involved in the 5' capping of viral RNA. Beyond the therapeutic aspects,

\footnotetext{
* Corresponding author: Patrick Di Martino ; E-mail : patrick.di-martino@cyu.fr

Laboratoire ERRMECe, CY Cergy-Paris Université, 1 rue Descartes, 95000 Neuville-sur-Oise, France.
} 
research on proteins and peptides related to Covid-19 is also directed towards the development of diagnostic tools. For example, analysis of the urinary proteomic profile can provide an early prognosis of complications in patients infected with SARS-Cov-2 [10]. The study of glycosylation of viral proteins and the ACE-2 receptor is important for the development of therapies and diagnostics [11]. Indeed, glycosylation sites can participate in immune evasion by protecting specific epitopes from neutralising antibodies. It is essential to control the glycosylation of recombinant viral proteins used for vaccine design or in the manufacture of serological test kits.

\section{Conclusion}

Peptide and protein research is essential in the fight against Covid-19 and Sars-Cov-2. It serves the development of new vaccines, new drugs and new diagnostic tools.

\section{Compliance with ethical standards}

\section{Acknowledgments}

The authors would like to thank the "CY Cergy-Paris Université" and the "Ecole de Biologie Industrielle" for their support.

\section{Disclosure of conflict of interest}

The authors declare that there is no conflict of interest.

\section{References}

[1] Hernández ASM, Rodríguez MSM, Rodriguez ASM. Emerging viral diseases. Open Access Res J Biol Pharmacy. 2021; 01(02): 20-27.

[2] Malik JA, Mull AH, Farooqi T, Pottoo FH, Anwar S. Rengasamy, K.R.R. Targets and strategies for vaccine development against SARS-CoV-2. Biomed Pharmacother. 2021; 137: 111254.

[3] Lu R, Zhao X, Li J, Niu P, Yang B, Wu H, et al. Genomic characterisation and epidemiology of 2019 novel coronavirus: implications for virus origins and receptor binding. Lancet. 2020; 395: 565-574.

[4] Rees-Spear C, Muir L, Griffith SA, Heaney J, Aldon Y, Snitselaar JL. et al. The effect of spike mutations on SARSCoV-2 neutralization. Cell Rep. 2021; 34: 108890.

[5] Lin L, Ting S, Yufei H, Wendong L, Yubo F, Jing Z. Epitope-based peptide vaccines predicted against novel coronavirus disease caused by SARS-CoV-2. Virus Res. 2020; 288: 198082.

[6] Patro LPP, Sathyaseelan C, Uttamrao PP, Rathinavelan T. Global variation in SARS-CoV-2 proteome and its implication in pre-lockdown emergence and dissemination of 5 dominant SARS-CoV-2 clades. Infect. Genet. Evol. 2021; 93: 104973.

[7] Akachar J, Bouricha EM, Hakmi M, Belyamani L, El Jaoudi R, Ibrahimi A. Identifying epitopes for cluster of differentiation and design of new peptides inhibitors against human SARS-CoV-2 spike RBD by an insilico approach. Heliyon. 2020; 6: e05739.

[8] Kreutzer AG, Krumberger M, Diessner EM, Parrocha CMT, Morris MA, Guaglianone G, et al. A cyclic peptide inhibitor of the SARS-CoV-2 main protease. Eur. J. Med. Chem. 2021; 221: 113530.

[9] Dutta M, Iype E. Peptide inhibitors against SARS-CoV-2 2'-O methyltransferase involved in RNA capping: A computational approach. Biochem. Biophys. Rep. 2021; 27: 101069.

[10] Wendt R, Thijs L, Kalbitz S, Mischak H, Siwy J, Raad J, et al. CRIT-COV-U investigators. A urinary peptidomic profile predicts outcome in SARS-CoV-2-infected patients. EClinicalMedicine. 2021; 36: 100883.

[11] Zhang Y, Zhao W, Mao Y, Chen Y, Wang S, Zhong Y, et al. Site-specific N-glycosylation Characterization of Recombinant SARS-CoV-2 Spike Proteins. Mol. Cell. Proteomics. 2021; 20: 100058. 